\title{
Congress announcement: PHARM Connect Congress for Enlarged Europe 2012
}

The Annual PHARM Connect Congress for Enlarged Europe 2012 is one of the largest pharmaceutical and biotechnology manufacturing events and the only regional one for Central and Eastern Europe in 2012. Therefore several associations are supporting the event, e.g. the Association of Hungarian Pharmaceutical Manufacturers (MAGYOSZ), the Polish Biotechnology Association (PFB), the Association of Innovative Pharmaceutical Manufacturers (AIPM), the Hungarian (HBA) and the Czech Biotechnology Association (CzechBio) as well as GS1.

The quality of the congress is a direct result of its exclusivity. The Programme Advisory Committee assures the highest relevance of the conference programme, which will include the most up-to-date market insights into R\&D, Production, Packaging, Logistics, Supply Chain and Quality Managementrelated topics. Confirmed committee members are:

- Prof. Tamás L. Paál, Senior Adviser, National Institute for Quality- and Organizational Development in Healthcare and Medicines, Hungary

- Prof. Vladimir Kral, Chemical Development Director, Zentiva, Czech Republic

- Prof. Ádám Vas, Senior Research Adviser, Gedeon Richter, Hungary

- Dr. Sergei Sur, R\&D Director, Arterium Corporation, Ukraine

- István Király, Senior Manager of Quality Assurance, GSK, Hungary

- Prof. Tomasz Twardowski, President, Polish Biotechnology Federation, Poland

- Ernő Duda, President, Hungarian Biotechnology Association, Hungary

- Dr. Péter Lakatos, Member of the Presidency at the Hungarian Logistics Association \& Head of Teva Logistic Center, TEVA, Hungary

The PHARM Connect Congress 2012 also provides an opportunity to visit the TEVA Logistics Centre in Gödöllő or the Sanofi plant in Veresegyház on February $9^{\text {th }}$, available on a first-come, first-serve basis.

Moreover, it is the perfect setting for local and international solution-providers to present their products and services directly to key decision-makers. Each solution-provider is selected based on requirements and interests stated by attending pharmaceutical professionals prior to the event.

Several weeks in advance of the event the TEG Meeting Scheduler is made available to every solutionprovider and delegate attending. Participants receive personalised passwords to access the website where they are able to select key presentations, pre-schedule one-to-one meetings and confirm their 
presence at several additional networking activities. Through the Meeting Scheduler participants have the opportunity to create their own itinerary prior to the congress taking place.

Do not miss this opportunity to network and establish connections, exchange ideas and gain knowledge!

Please visit our website to learn more about this prestigious congress taking place on February 08 - 09 at the CORINTHIA Grand Hotel Royal in the heart of Budapest, a venue which is truly a one of a kind: www.pharmconnect.eu 